\section{An Efficient Procedure for Regeneration from Leaf-derived Calluses of Lonicera macranthoides 'Jincuilei', an Important Medicinal Plant}

\author{
Xiaoming Wang ${ }^{1}$ \\ Central South University of Forestry and Technology and Hunan Academy of \\ Forestry, Changsha, Hunan Province 410004, China
}

Jianjun Chen ${ }^{1}$

University of Florida, IFAS, Environmental Horticulture Department

and Mid-Florida Research and Education Center, 2725 Binion Road,

Apopka, FL 32703

\section{Yongxin Li, Qiying Nie, and Junbin Li \\ Hunan Academy of Forestry, Changsha, Hunan Province 410004, China}

Additional index words. chlorogenic acid, ornamental honeysuckles, shoot organogenesis of Lonicera

\begin{abstract}
Jincuilei' is a mutant selected from Lonicera macranthoides Hand.-Mazz. It produces abundant flowers that never open with a chlorogenic acid (CGA) content up to $6.0 \%$. Propagation through rooting or grafting has only a $30 \%$ survival rate. This study was undertaken to establish an efficient protocol for rapidly regenerating this mutant. Leaf explants were inoculated on Gamborg's $B_{5}$ medium supplemented with different concentrations of 6-benzyladenine (BA) and 2,4-dichlorophenozyacetic acid (2,4-D). The optimal combination for callus induction was $4.4 \mu \mathrm{M}$ BA with $2.26 \mu \mathrm{M}$ 2,4-D, which resulted in $86.7 \%$ of leaf explants producing calluses in 4 weeks. Calluses produced from this optimal medium were cultured on $B_{5}$ medium containing different concentrations of kinetin (KT) and $\alpha$-naphthalene acetic acid (NAA). The best formulation for shoot induction was $B_{5}$ medium containing $0.9 \mu \mathrm{M}$ KT and $5.4 \mu \mathrm{M}$ NAA in which $73.4 \%$ of cultured calluses produced shoots in 8 weeks, and shoot numbers ranged from three to six per callus piece $\left(1 \mathrm{~cm}^{3}\right)$. Adventitious shoots were cut and rooted in half-strength Murashige and Skoog medium supplemented with $14.8 \mu \mathrm{m}$ 3-indolebutyric acid. Roots initiated $10 \mathrm{~d}$ after culture, and rooting percentages ranged from $98 \%$ to $100 \%$. Plantlets grown in a container substrate in a shaded greenhouse had over a $95 \%$ survival rate. During the last 6 years, over four million plantlets were regenerated using this established procedure, and there was no somaclonal variation. Fresh and dry weights of 1000 flowers, CGA contents, and dry flower yields of the regenerated plants were not significantly different from those of the stock 'Jincuilei' propagated by cutting, indicating that plants regenerated from this established procedure were stable. This established in vitro culture method has led to rapid commercial production of this medicinal plant on more than $\mathbf{1 5 0 0}$ ha of production field.
\end{abstract}

Lonicera L., commonly known as honeysuckle, is a genus of woody plants and belongs to the family Caprifoliaceae. There are 180 recognized species of deciduous or evergreen, bushy, candent, twining or creeping shrubs distributed in Asia, Europe, and North America (Huxley, 1994). Flowers are

Received for publication 12 Dec. 2008. Accepted for publication $5 \mathrm{Feb} .2009$

This research was supported in part by the Hunan Province Forestry Department, Hunan, China. We thank Russell D. Caldwell for critical review of the manuscript.

${ }^{1}$ To whom reprint requests should be addressed; e-mailwxm1964@163.com or jjchen@ufl.edu. bacteriostasis, antivirus, antioxidant, and hematischesis (Lee et al., 1998; Palacios et al., 2002; Peng et al., 2005). Flos lonicerae contains a series of water-soluble phenolic compounds with 3-O-ceffeoyl-D-quinic acid or chlorogenic acid (CGA) being a major ingredient. In addition to having antipyretic properties, CGA has been reported to suppress $N$-nitrosating reactions and inhibit hepatic glucose 6-phosphatase, which may be a significant factor in the abnormal diabetic state (Arion et al., 1997; Yang et al., 2004). CGA has been studied in $L$. confuse DC., L. dasystyla Rehder, L. hypoglauca Miq. (Guo and Wan, 2005; Li et al., 2003), L. japonica (Lee et al., 1998), and L. tatarica L. (Palacios et al., 2002).

Another species, L. macranthoides Hand.Mazz., native to China (Xu and Wang, 1988), was found to contain much higher concentrations of CGA $(4.0 \%$ to $4.5 \%)$ than $L$. japonica (2.2\% to $2.5 \%$ ) (Zhou and Tong, 2003). A survey of genetic resources of Lonicera in southwest Hunan province, China, in 1997 to 1998 resulted in the identification of a mutant from a L. macranthoides population that was heavily infected with powdery mildew disease (Microsphaera lonicerae DC.). The mutant (Fig. 1A), in contrast to its wild type (Fig. 1B), resists the powdery mildew and possesses abundant flowers that never open. Wang et al. (2004) documented that the mutant had an average of 30 nonopened flowers per axillary and the flower longevity ranged from 15 to $25 \mathrm{~d}$ compared with 5 to 7 $\mathrm{d}$ of the wild-type plants. The mutant was named 'Jincuilei'. CGA concentration in the nonopened flowers of 'Jincuilei' was higher, up to $6.0 \%$ compared with $4.3 \%$ in its wildtype plants. This mutant, however, does not produce seeds and propagation by cutting or grafting has only a $\approx 30 \%$ survival rate (Wang et al., 2004), which significantly hampers its commercial production as a medicinal plant.

In vitro culture has been shown to be an efficient method of propagating medicinal plants (Debnath et al., 2006; Rout et al., 2000). Research on micropropagation of 'Jincuilei' started in 2000. A method of eliminating contaminants from leaf explants was established (Wang et al., 2005). $\mathrm{B}_{5}$ medium (Gamborg et al., 1968), Murashige and Skoog (MS) medium (Murashige and Skoog, 1962), woody plant medium (Lloyd and McCown, 1980), and White basal medium (White, 1963) were tested for culture of leaf explants. However, a simple and efficient protocol for rapid regeneration of 'Jincuilei' was not well developed. The objectives of this study were to establish an efficient procedure for inducing callus and adventitious shoot formation of 'Jincuilei' and determine if the regenerated plants maintained the nonopened flower characteristic and high level of CGA.

\section{Materials and Methods} called "Jinyinhua" in Chinese or flo lonicerae, which is a famous herb of traditional Chinese medicine. Extracts of flos lonicerae have a wide range of benefits to human health, including anti-inflammation, 


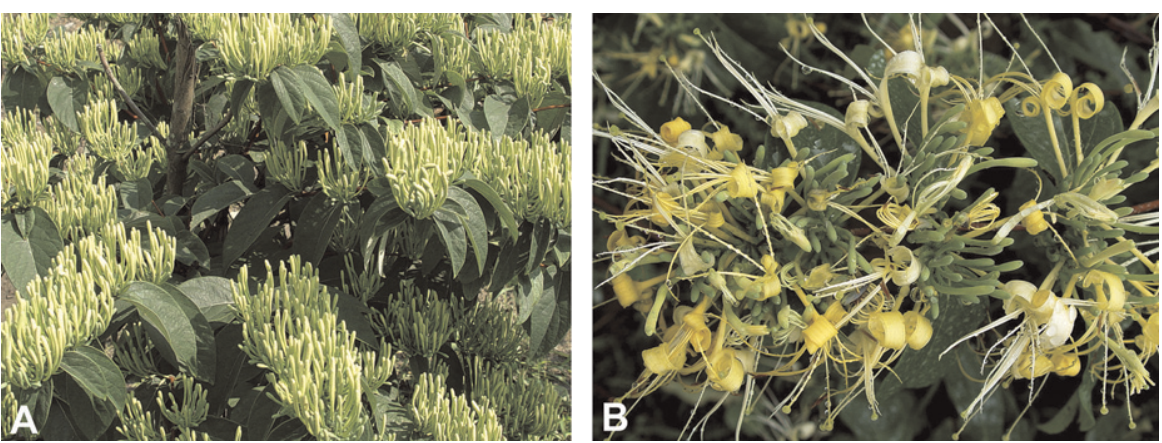

Fig. 1. Three-year-old Lonicera macranthoides 'Jincuilei' regenerated through indirect shoot organogenesis and its wild-type propagated through cuttings. (A) 'Jincuilei' with abundant nonopened flowers; (B) the wild-type plants with open flowers and flowers to open.

water followed by a spray of the tissue surface with $75 \%$ ethanol for $10 \mathrm{~s}$. The leaves were sterilized in separate bottles containing $0.1 \% \mathrm{HgCl}_{2}$ and two to three drops of Tween 80 for $5 \mathrm{~min}$ with occasional agitation (Wang et al., 2005). After pouring out the $\mathrm{HgCl}_{2}$ solution, leaves were rinsed three times with sterile distilled water and cut into $\approx 0.5-\mathrm{cm}^{2}$ pieces in sterile petri dishes for inoculation.

Medium preparation. $\mathrm{B}_{5}$ medium with $0.7 \%(\mathrm{w} / \mathrm{v})$ agar (ash: $2 \%$ to $4 \%$; Mingfu Fujian Agar Co., Ltd., Sanming City, China) and $3.0 \%(\mathrm{w} / \mathrm{v})$ sucrose was prepared, and the medium $\mathrm{pH}$ was adjusted to 5.8 with $1 \mathrm{M}$ $\mathrm{KOH}$ before autoclaving at $121{ }^{\circ} \mathrm{C}$ for 25 min. Plant growth regulator solutions of 6benzyladenine (BA), kinetin (KT), $\alpha$-naphthalene acetic acid (NAA), or 2,4-dichlorophenozyacetic acid (2,4-D) were filtersterilized and added in different combinations to the autoclaved medium when the temperature dropped to $\approx 50{ }^{\circ} \mathrm{C}$.

Callus induction. The medium for callus induction was the $\mathrm{B}_{5}$ medium supplemented with $0,2.2,4.4$, and $13.3 \mu \mathrm{M}$ BA with $0,2.3$, 4.5, and $13.6 \mu \mathrm{M} 2,4-\mathrm{D}$ in 16 combinations. The prepared medium was aliquoted into autoclaved $300-\mathrm{mL}$ flasks at $30 \mathrm{~mL}$ each. After agar solidification, three leaf explants were placed on the callus induction medium with the adaxial surface up. Based on the percentage of cultured leaf explants in callus formation, the optimal combination of growth regulators for callus induction was identified. A large number of calluses were produced from leaf explants cultured only on this formulation. To minimize the potential of somaclonal variation, only those calluses that were initially induced from leaf explants 4 weeks after culture were used for adventitious shoot induction.

Shoot induction. The calluses were cut into $1-\mathrm{cm}^{3}$ pieces $(\approx 150 \mathrm{mg}$ in fresh weight) and cultured on shoot induction medium with three callus pieces per flask. The shoot induction medium was $\mathrm{B}_{5}$ containing $\mathrm{KT}$ at $0,0.5,0.9$, $2.3 \mu \mathrm{M}$ and NAA at $0,2.7,5.4$, and $16.1 \mu \mathrm{M}$ in 16 combinations. Based on the percentage of the cultured callus pieces with shoots, the best formulation for shoot induction was identified. This formulation was used for inducing a large number of shoots from calluses.
Rooting. Adventitious shoots with a height $\approx 2$ or $3 \mathrm{~cm}$ were excised and rooted in half-strength MS medium containing 14.8 $\mu \mathrm{M} 3$-indolebutyric acid (IBA). The selection of $14.8 \mu \mathrm{M}$ IBA was based on a preliminary experiment conducted on half-strength MS medium with different concentrations of IBA. The remaining calluses were discarded because their subculture resulted in quick browning and death.

Culture conditions. Cultures for both callus induction and shoot formation as well as for rooting were maintained in a culture room under a 12 -h photoperiod provided by cool-white fluorescent lamps with a photon flux density of $50 \mu \mathrm{mol} \cdot \mathrm{m}^{-2} \cdot \mathrm{s}^{-1}$ and temperature of $25 \pm 2{ }^{\circ} \mathrm{C}$.

Transplanting and acclimatization. After washing off the rooting medium with tap water, plantlets were transplanted to plastic pots containing a substrate comprised of $20 \%$ clay soil, $40 \%$ carbonized rice hull, and $40 \%$ coarse sand based on volume. They were grown in a shaded greenhouse under a maximum photosynthetically active photon flux density of $200 \mu \mathrm{mol} \cdot \mathrm{m}^{-2} \cdot \mathrm{s}^{-1}$, temperature range of 20 to $28{ }^{\circ} \mathrm{C}$, and relative humidity of $70 \%$ to $100 \%$. Survival rates of plantlets were recorded 2 months after transplanting.

Comparison of flower yield and chlorogenic acid concentration. Four months after acclimatization, regenerated plants along with cutting propagated stock 'Jincuilei' and its wild-type plants were planted on production fields. A nitrogen-phosphate-potash fertilizer with a ratio of 30-10-10 was applied annually at $1500 \mathrm{~kg} \cdot \mathrm{ha}^{-1}$. The experiment was arranged in a completely randomized block design with 10 replications. Two years after planting, all plants started flowering. In the third year, fresh and dry weight of 1000 flowers, dry flower yield of per unit area, and CGA content in the three types of plants were determined.

Chlorogenic acid analysis. CGA was determined by ultraviolet spectrophotometry (Dao and Friedman, 1992). Briefly, fresh flowers from regenerated 'Jincuilei', stock 'Jincuilei', and wild-type plants were collected and frozen in liquid nitrogen $6 \mathrm{~d}$ after the flower appearance (at this time, flowers had not opened in the wild-type plants). The frozen samples were lyophilized and the dried samples were ground in a Wiley mill to pass a 40 -mesh screen. The powders were stored in a refrigerator at $-80{ }^{\circ} \mathrm{C}$. Samples were extracted using $100 \%$ ethyl alcohol for $18 \mathrm{~h}$. The ultraviolet spectrum, 220 to 400 $\mathrm{nm}$, was determined in the ethyl alcohol extract after suitable dilution with ethanol. The concentrations of chlorogenic acid were calculated from the absorption maximum at 326 to $328 \mathrm{~nm}$ from a standard curve prepared using chlorogenic acid obtained from Sigma-Aldrich, Co. (St. Louis, MO). The molar extinction coefficient of chlorogenic acid was determined as 19,100 ( $\mathrm{n}=10)$ compared with a reported Merck Index value of 19,200 (Windholz, 1976).

Data collection and analysis. Each flask was considered an experimental unit for callus induction and shoot formation. There were 10 replications for each treatment. Explants that responded to callus induction were recorded 2 and 4 weeks after culture, and calluses responding to shoot induction were recorded 6 and 8 weeks after inoculation. Data for rooting was collected $15 \mathrm{~d}$ after shoots were transferred to rooting medium. After checking normal distribution, analysis of variance for percentages of leaf explants with callus formation and callus pieces with shoot formation were analyzed using SPSS 13.0 for Windows (SPSS, Chicago, IL). Additionally, flower yield and CGA content of regenerated and cutting propagated 'Jincuilei' plants as well as the wild-type plants were analyzed. When significant differences $(P<0.05)$ occurred, means were separated using Fisher's protected least significant differences at $P<0.05$.

\section{Results}

Callus induction. The cut edge of leaf explants started to expand $3 \mathrm{~d}$ after inoculation, and the entire leaf explants expanded $5 \mathrm{~d}$ later (Fig. 2A). Small yellowish particles appeared on explant edges 2 weeks after culture on $\mathrm{B}_{5}$ medium supplemented with $2.3,4.5$, and $13.6 \mu \mathrm{M} 2,4-\mathrm{D}$ or $2,4-\mathrm{D}$ at these concentrations with 2.2, 4.4, and $13.3 \mu \mathrm{M} \mathrm{BA}$, respectively (Table 1 ). Rapid callus formation occurred in 3 to 4 weeks (Fig. 2B). Growth regulator treatments had significant effects on callus formation. No calluses occurred in explants cultured on the $\mathrm{B}_{5}$ medium devoid of growth regulators or containing BA only. Callus formation frequencies of leaf explants cultured on medium containing $2,4-\mathrm{D}$ only ranged from $10 \%$ to $20 \%$, which were significantly lower than those cultured on medium containing both BA and 2,4-D regardless of 2 or 4 weeks of culture. The combinations of BA at the three concentrations with $2.3 \mu_{\mathrm{M}}$ 2,4-D generally resulted in greater callus formation frequencies than the BA concentrations with the two other 2,4-D concentrations. Although callus formation frequencies on medium containing $2.2 \mu \mathrm{M}$ BA with $2.3 \mu \mathrm{M} 2,4-\mathrm{D}$ and $4.4 \mu \mathrm{M}$ BA with $2.3 \mu \mathrm{M} 2,4-\mathrm{D}$ were similar at both 2 and 4 weeks of culture, the combination of $4.4 \mu \mathrm{M}$ 

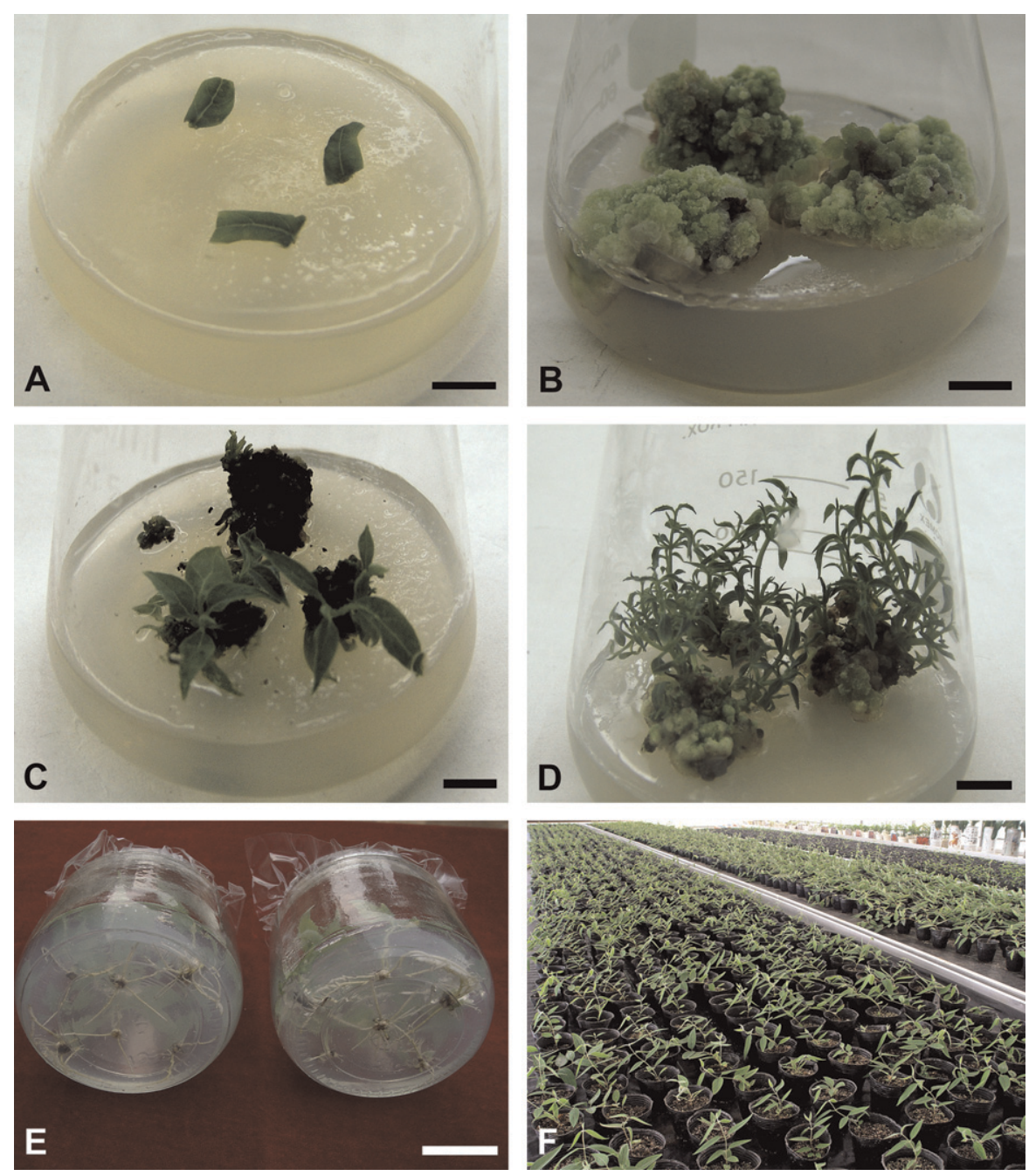

Fig. 2. Morphogenesis of Lonicera macranthoides 'Jincuilei' through indirect shoot organogenesis. (A) Leaf explants of 'Jincuilei' cultured on a callus induction medium $3 \mathrm{~d}$ after inoculation. (B) Callus proliferation occurred in leaf explants cultured on $\mathrm{B}_{5}$ medium containing $4.4 \mu \mathrm{M} 6$-benzyladenine and $2.3 \mu \mathrm{M}$ 2,4-dichlorophenozyacetic acid 4 weeks after culture. (C) Adventitious shoots initiated from calluses and grew in a shoot induction medium. (D) The vigorous growth of adventitious shoots occurred in $\mathrm{B}_{5}$ medium containing $0.9 \mu \mathrm{M}$ kinetin and $5.4 \mu \mathrm{M} \alpha$-naphthalene acetic acid. (E) Adventitious shoots rooted in half-strength Murashige and Skoog medium containing $14.8 \mu \mathrm{M} 3$-indolebutyric acid. (F) Plantlets were grown in containers with a substrate comprised of $20 \%$ clay soil, $40 \%$ carbonized rice hull, and $40 \%$ coarse sand based on volume in a shaded greenhouse under a maximum photosynthetically active photon flux density of $200 \mu \mathrm{mol} \cdot \mathrm{m}^{-2} \cdot \mathrm{s}^{-1}$. Bars $=10 \mathrm{~mm}$.

BA and $2.3 \mu \mathrm{M} 2,4-\mathrm{D}$ was selected as the optimal combination for callus induction because it resulted in $86.7 \%$ of leaf explants producing calluses 4 weeks after culture.

Shoot induction. Leaf primordia became visible 4 weeks after callus pieces were cultured on shoot induction medium containing both KT and NAA or KT only at concentrations of 0.9 or $2.3 \mu \mathrm{M}$; adventitious shoots appeared 2 weeks later (Fig. 2C). Shoots, however, were not induced from calluses cultured on medium devoid of growth regulators or containing NAA only at the 2.7, 5.4, and 16.1 $\mu_{\mathrm{M}}$ (Table 2). Shoot formation frequencies 6 weeks after callus pieces were cultured on medium containing $0.9 \mu \mathrm{M}$ KT with $2.7,5.4$, or $16.1 \mu \mathrm{M}$ NAA were significantly higher $(36.7 \%$ to $50 \%)$ than those cultured on medium containing 0.5 or $2.3 \mu \mathrm{M}$ KT with $2.7,5.4$, or $16.1 \mu \mathrm{M}$ NAA $(3.3 \%$ to
$16.7 \%)$. The differences became more pronounced 8 weeks after inoculation. Shoot formation frequencies of calluses cultured on medium containing $0.9 \mu \mathrm{M} \mathrm{KT}$ with 2.7 , 5.4 , or $16.1 \mu \mathrm{M}$ NAA ranged from $46.7 \%$ to $73.4 \%$ compared with a range of $10.0 \%$ to $26.7 \%$ when calluses were cultured on medium containing 0.5 or $2.3 \mu \mathrm{M} \mathrm{KT}$ with $2.7,5.4$, and $16.1 \mu \mathrm{M}$ NAA, respectively. The best formulation was $\mathrm{B}_{5}$ medium containing $0.9 \mu \mathrm{M} \mathrm{KT}$ and $5.4 \mu \mathrm{M}$ NAA in which $73.4 \%$ of cultured callus pieces produced adventitious shoots with shoot numbers ranging from three to six (Fig. 2D).

Rooting and acclimatization. Microcuttings were rooted $10 \mathrm{~d}$ after culture on rooting medium. On average, four roots were produced per shoot $25 \mathrm{~d}$ later (Fig. 2E). Rooting percentage ranged from $98 \%$ to $100 \%$ (data not shown). Plantlets grown in the container substrate in the shaded greenhouse had over a 95\% survival rate (Fig. 2F). After the establishment of this regeneration protocol, four million plantlets were produced. These regenerated plants were planted on over 1500 ha of production field for commercial 'Jincuilei' production.

Comparison of flower yield and chlorogenic acid concentration. No somaclonal variation was observed in the regenerated plants because all the regenerated plants had the same phenotype as 'Jincuilei' propagated by cutting. Regenerated plants produced abundant nonopened flowers. Fresh and dry weight of 1000 flowers, CGA content, and dry flower yield of the regenerated 'Jincuilei' were similar to those of 'Jincuilei' plants propagated by cutting (Table 3 ). These results indicated that plants regenerated from this established method had no variation in flower yield and CGA content from 'Jincuilei' propagated by cutting. However, such measured parameters varied significantly between 'Jincuilei' and its wild-type plants.

\section{Discussion}

In vitro culture has been used to manipulate several Lonicera species, and in some instances, whole plants have been regenerated. Shoot proliferation was achieved using single nodes of $L$. periclymenum L. (Boonnour et al., 1988), L. caerulea L. (Karhu, 1997), and L. tatarica (Palacios et al., 2002). Indirect shoot organogenesis was established using leaf explants of L. japonica (Georges et al., 1993) and L. nitida E. H. Wilson (Cambecedes et al., 1991) as well as leaf protoplasts of L. nitida (Ochatt, 1991). However, there has been limited information available regarding the regeneration of $L$. macranthoides. In this study, we established an efficient procedure for regeneration of a mutant of $L$. macranthoides through indirect shoot organogenesis, i.e., callus induction from leaf explants on $\mathrm{B}_{5}$ medium containing $4.4 \mu \mathrm{M}$ BA and $2.3 \mu \mathrm{M} 2,4-\mathrm{D}$ in 4 weeks; shoot induction from calluses on $\mathrm{B}_{5}$ medium supplemented with $0.9 \mu \mathrm{M}$ KT with $5.4 \mu \mathrm{m}$ NAA in 8 weeks; and rooting of adventitious shoots in half-strength MS medium containing $14.8 \mu \mathrm{M}$ IBA in 4 weeks.

The callus induction method is simple and convenient with the use of leaf explants. Compared with the other callus induction media for other Lonicera, this established medium is more effective because $86.7 \%$ of leaf explants of 'Jincuilei' produced calluses in only 2 to 4 weeks after culture. A callus induction medium, MS containing $2.3 \mu \mathrm{M} \mathrm{N}$ phenyl-N'-1,2,3-thiadiazol-5-ylurea (TDZ) and $2.9 \mu \mathrm{M}$ 3-indoleacetic acid developed by Cambecedes et al. (1991), induced $56.6 \%$ of leaf explants producing calluses in 15 weeks. Callus induction from leaf explants of L. japonica on Linsmaier and Skoog (1965) medium supplemented with $10.7 \mu \mathrm{M}$ NAA and $2.7 \mu \mathrm{M}$ BA took 25 weeks (Georges et al., 1993). Additionally, Linsmaier and Skoog (1965) medium containing $0.45 \mu \mathrm{M}$ 
Table 1. Frequency of callus formation from leaf explants of Lonicera macranthiodes 'Jincuilei' cultured 2 and 4 weeks on $\mathrm{B}_{5}$ medium $^{\mathrm{z}}$ supplemented with different concentrations of BA and 2,4-D. ${ }^{\mathrm{y}}$

\begin{tabular}{rrrr}
\hline \multicolumn{2}{c}{ Growth regulators $(\mu \mathrm{M})$} & \multicolumn{2}{c}{ Frequency of explants with callus formed $(\%)$} \\
\cline { 2 - 4 } BA & $2,4-\mathrm{D}$ & \multicolumn{1}{c}{2 weeks } & 4 weeks \\
\hline 0.0 & 0.0 & $0.0 \pm 0.00 \mathrm{f}^{\mathrm{x}}$ & $0.0 \pm 0.00 \mathrm{f}$ \\
0.0 & 2.3 & $10.0 \pm 0.16 \mathrm{e}$ & $23.3 \pm 0.23 \mathrm{e}$ \\
0.0 & 4.5 & $20.0 \pm 0.23 \mathrm{~d}$ & $36.7 \pm 0.25 \mathrm{~d}$ \\
0.0 & 13.6 & $16.7 \pm 0.24 \mathrm{de}$ & $36.7 \pm 0.19 \mathrm{~d}$ \\
2.2 & 0.0 & $43.3 \pm 0.00 \mathrm{f}$ & $0.0 \pm 0.00 \mathrm{~g}$ \\
2.2 & 2.3 & $36.7 \pm 0.25 \mathrm{~b}$ & $83.4 \pm 0.18 \mathrm{a}$ \\
2.2 & 4.5 & $26.7 \pm 0.26 \mathrm{c}$ & $66.7 \pm 0.22 \mathrm{~b}$ \\
2.2 & 13.6 & $0.0 \pm 0.00 \mathrm{f}$ & $53.3 \pm 0.17 \mathrm{c}$ \\
4.4 & 0.0 & $43.3 \pm 0.23 \mathrm{a}$ & $0.0 \pm 0.00 \mathrm{~g}$ \\
4.4 & 2.3 & $40.0 \pm 0.21 \mathrm{a}$ & $86.7 \pm 0.17 \mathrm{a}$ \\
4.4 & 4.5 & $33.3 \pm 0.22 \mathrm{~b}$ & $73.7 \pm 0.23 \mathrm{ab}$ \\
4.4 & 13.6 & $0.0 \pm 0.00 \mathrm{f}$ & $60.0 \pm 0.21 \mathrm{~b}$ \\
13.3 & 0.0 & $40.0 \pm 0.21 \mathrm{a}$ & $0.0 \pm 0.00 \mathrm{f}$ \\
13.3 & 2.3 & $33.0 \pm 0.22 \mathrm{~b}$ & $66.7 \pm 0.25 \mathrm{~b}$ \\
13.3 & 4.5 & $26.7 \pm 0.21 \mathrm{c}$ & $56.7 \pm 0.23 \mathrm{bc}$ \\
13.3 & 13.6 & $46.7 \pm 0.17 \mathrm{c}$ \\
\hline
\end{tabular}

${ }^{\mathrm{z}}$ Gamborg $\mathrm{B}_{5}$ medium supplemented with $0.7 \%(\mathrm{w} / \mathrm{v})$ agar and $3.0 \%(\mathrm{w} / \mathrm{v})$ sucrose.

${ }^{\mathrm{y}}$ Three leaf explants per $300-\mathrm{mL}$ flask and 10 flasks per treatment.

${ }^{x}$ Different letters within a column represent significant difference at $P<0.5$ by Fisher's protected least significant difference test.

$\mathrm{BA}=6$-benzyladenine; 2,4-D = 2,4-dichlorophenozyacetic acid

Table 2. The frequency of shoot formation from cultured callus pieces of Lonicera macranthiodes 'Jincuilei' 6 and 8 weeks after inoculation on $B_{5}$ medium $^{z}$ supplemented with different concentrations of KT and NAA. ${ }^{y}$

\begin{tabular}{crcc}
\hline \multicolumn{2}{c}{ Growth regulators $(\mu \mathrm{M})$} & \multicolumn{2}{c}{ Frequency of callus pieces with shoot formation $(\%)$} \\
\cline { 2 - 3 } Kinetin & NAA & 6 weeks & 8 weeks \\
\hline 0.0 & 0.0 & $0.0 \pm 0.00 \mathrm{f}^{\mathrm{x}}$ & $0.0 \pm 0.00 \mathrm{~g}$ \\
0.0 & 2.7 & $0.0 \pm 0.00 \mathrm{f}$ & $0.0 \pm 0.00 \mathrm{~g}$ \\
0.0 & 5.4 & $0.0 \pm 0.00 \mathrm{f}$ & $0.0 \pm 0.00 \mathrm{~g}$ \\
0.0 & 16.1 & $0.0 \pm 0.00 \mathrm{f}$ & $0.0 \pm 0.00 \mathrm{~g}$ \\
0.5 & 0.0 & $0.0 \pm 0.00 \mathrm{f}$ & $6.7 \pm 0.14 \mathrm{f}$ \\
0.5 & 2.7 & $6.7 \pm 0.14 \mathrm{~d}$ & $13.3 \pm 0.17 \mathrm{e}$ \\
0.5 & 5.4 & $10.0 \pm 0.16 \mathrm{~cd}$ & $16.7 \pm 0.24 \mathrm{e}$ \\
0.5 & 16.1 & $6.7 \pm 0.14 \mathrm{~d}$ & $13.3 \pm 0.23 \mathrm{e}$ \\
0.9 & 0.0 & $13.3 \pm 0.17 \mathrm{c}$ & $26.7 \pm 0.21 \mathrm{~d}$ \\
0.9 & 2.7 & $56.7 \pm 0.25 \mathrm{~b}$ & $56.7 \pm 0.23 \mathrm{~b}$ \\
0.9 & 5.4 & $30.0 \pm 0.24 \mathrm{a}$ & $73.4 \pm 0.21 \mathrm{a}$ \\
0.9 & 16.1 & $6.7 \pm 0.14 \mathrm{~d}$ & $46.7 \pm 0.23 \mathrm{c}$ \\
2.3 & 0.0 & $6.7 \pm 0.14 \mathrm{~d}$ & $16.7 \pm 0.24 \mathrm{e}$ \\
2.3 & 2.7 & $16.7 \pm 0.24 \mathrm{c}$ & $13.3 \pm 0.23 \mathrm{e}$ \\
2.3 & 5.4 & $3.3 \pm 0.11 \mathrm{e}$ & $26.7 \pm 0.26 \mathrm{~d}$ \\
2.3 & 16.1 & $10.0 \pm 0.23 \mathrm{e}$ \\
\hline
\end{tabular}

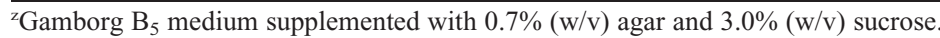

${ }^{y}$ Three callus pieces $\left(1 \mathrm{~cm}^{3}\right)$ per $300-\mathrm{mL}$ flask and 10 flasks per treatment.

${ }^{\times}$Different letters within a column represent significant difference at $P<0.5$ by Fisher's protected least significant difference test.

$\mathrm{KT}=$ kinetin or 6 -furfurylaminopurine; NAA $=\alpha$-naphthalene acetic acid.

Table 3. Fresh and dry weight of 1000 flowers, flower chlorogenic acid (CGA) content, and dry flower yield of the wild-type Lonicera macranthoides, stock 'Jincuilei' propagated by cuttings and regenerated 'Jincuilei' in their third year after planting on the production field.

\begin{tabular}{lcccc}
\hline Plant & $\begin{array}{c}\text { Flower fresh wt } \\
(\mathrm{g} / 1000 \text { flowers })\end{array}$ & $\begin{array}{c}\text { Flower dry wt } \\
(\mathrm{g} / 1000 \text { flowers })\end{array}$ & $\begin{array}{c}\text { CGA content } \\
(\%)\end{array}$ & $\begin{array}{c}\text { Dry flower yield } \\
\left(\mathrm{kg} \cdot \mathrm{ha}^{-1}\right)\end{array}$ \\
\hline Wild type & $56.4 \mathrm{~b}^{\mathrm{z}}$ & $13.3 \mathrm{~b}$ & $4.3 \mathrm{~b}$ & $1,462.8 \mathrm{~b}$ \\
Stock Jincuilei & $73.4 \mathrm{a}$ & $17.6 \mathrm{a}$ & $5.9 \mathrm{a}$ & $3,377.2 \mathrm{a}$ \\
Regenerated Jincuilei & $74.1 \mathrm{a}$ & $17.9 \mathrm{a}$ & $6.0 \mathrm{a}$ & $3,385.6 \mathrm{a}$ \\
\hline
\end{tabular}

${ }^{\mathrm{z}}$ Means followed by different letters are significantly different at $P<0.05$ by Fisher's protected least significant difference test. Data represent means of 10 replications.

2,4-D resulted in the rapid necrosis of leaf explants of $L$. japonica (Georges et al., 1993). There was no necrosis on leaf explants of $L$. macranthoides 'Jincuilei' cultured on $\mathrm{B}_{5}$ medium containing up to $13.6 \mu_{\mathrm{M}} 2,4-\mathrm{D}$. The high efficiency of callus induction in L. macranthoides could be attributed to the genetic makeup of this species, the $\mathrm{B}_{5}$
$\mu_{\mathrm{M}}$ TDZ and $20 \mu_{\mathrm{M}}$ 2,3,5-triiodobenzoic acid (Cambecedes et al., 1991) and 44\% for calluses of $L$. japonica cultured on woody plant medium containing 4.4 to $44.4 \mu \mathrm{M}$ BA for 13 weeks (Georges et al., 1993). Adventitious shoots of $L$. macranthoides 'Jincuilei' appeared within 6 weeks after callus culture, and up to $73.4 \%$ of cultured callus pieces produced shoots after 8 weeks on $\mathrm{B}_{5}$ medium containing $0.9 \mu \mathrm{M}$ KT with $5.4 \mu \mathrm{M}$ NAA. BA is considered more effective in shoot induction than KT (Georges et al., 1993). In one of our preliminary shoot induction studies, BA at concentrations of $4.4,13.3$, and $22.2 \mu \mathrm{M}$ only or with NAA at 2.7, 5.4, and $16.1 \mu \mathrm{M}$, respectively, did not result in shoot formation frequencies greater than 50\% (data not shown). On other hand, KT with NAA was found to be more effective in shoot induction of 'Jincuilei'.

In general, the most difficult stage for regeneration of woody species is the induction of roots from shoots (Bonga, 1977). Adventitious shoots of 'Jincuilei' readily rooted in half-strength MS medium containing $14.76 \mu \mathrm{M}$ IBA with a rooting percentage as high as $100 \%$ (data not shown). This ease in rooting characteristic was similar to that of L. nitida (Cambecedes et al., 1991; Ochatt, 1991) in which high endogenous IBA in Lonicera was assumed to be a factor.

Indirect shoot organogenesis is often associated with somaclonal variation (Chen and Henny, 2006; Skirvin et al., 1994). The duration of in vitro culture has been shown to be an important factor. Somaclonal variation generally increases with the time that a culture has been maintained in vitro (Bouman and De Klerk, 1997; Skirvin et al., 1994). No somaclonal variation was observed among four million regenerated plants because all the regenerated plants had the same morphology as 'Jincuilei' propagated by cutting. The flower yield and CGA content of the regenerated plants were comparable to those of cutting-propagated 'Jincuilei'. In addition to the plant genotype, the high genetic fidelity among the regenerated plants could be in part attributed to this established regeneration procedure in which calluses used for shoot induction were directly induced from leaf explants and not from subculture. Additionally, the regeneration process from culture of leaf explants to excision of adventitious shoots took only $\approx 12$ weeks, which might also help minimize the potential for somaclonal variation. Nevertheless, this established method resulted in the planting of over 1500 ha of regenerated 'Jincuilei'. A large quantity of nonopened flowers has been produced and processed as flos lonicerae for medicinal use.

\section{Literature Cited}

medium, appropriate growth regulators, or a combination of the three factors.

The shoot induction medium for 'Jincuilei' was either equal to or more effective than those reported with the other Lonicera species. The occurrence of shoots from callused explants was $74 \%$ in $L$. nitida after 8 weeks of culture on half-strength MS medium containing 2.3
Arion, W.J., W.K. Canfield, F.C. Ramos, P.W. Schindler, H. Burger, H. Hemmerle, G. Schubert, P. Below, and A.W. Herling. 1997. Chlorogenic acid and hydroxynitrobenzaldehyde: New inhibitors of hepatic glucose 6-phosphatase. Arch. Biochem. Biophys. 339:315-322.

Bonga, J. 1977. Application of tissue culture in forestry, p. 93-108. In: Reinert, J. and Y. Bajaj (eds.). Applied and fundamental aspects of 
plant cell, tissue and organ culture. Springer, New York, NY.

Boonnour, K., H. Wainwright, and R.G.T. Hicks. 1988. The micropropagation of Lonicera periclymenum L. (Honeysuckle). Acta Hort. 226:183190.

Bouman, H. and G. De Klerk. 1997. Somaclonal variation, p. 165-183. In: Geneve, R.L., J.E. Preece, and S.A. Merkle (eds.). Biotechnology of ornamental plants. CAB International, Wallingford, UK.

Cambecedes, J., M. Duron, and L. Decourtye. 1991. Adventitious bud regeneration from leaf explants of the shrubby ornamental honeysuckle, Lonicera nitida Wils. cv. Maigrun: Effects of thidiazuron and 2,3,5-triiodobenzoic acid. Plant Cell Rpt. 10:471-474.

Chen, J. and R.J. Henny. 2006. Somaclonal variation: An important source for cultivar development of floriculture crops, p. 244-253. In: Teixeira da Silva, J.A. (ed.). Floriculture, ornamental and plant biotechnology. Global Science Books, London, UK.

Dao, L. and M. Friedman. 1992. Chlorogenic acid content of fresh and processed potatoes determined by ultraviolet spectrophotometry. J. Agr. Food Chem. 40:2152-2156.

Debnath, M., C.P. Malik, and P.S. Bisen. 2006. Micropropagation: A tool for the production of high quality plant-based medicines. Curr. Pharm. Biotechnol. 7:33-49.

Gamborg, O.L., R.A. Miller, and K. Ojima. 1968 Nutrient requirements of suspension cultures of soybean root cells. Exp. Cell Res. 50:151-158.

Georges, D., J.C. Chenieux, and S.J. Ochatt. 1993. Plant regeneration from aged-callus of the woody ornamental species Lonicera japonica cv. Hall's Prolific. Plant Cell Rpt. 13:91-94.

Georges, D., L. Decourtye, and S.J. Ochatt. 1992. Biotechnological breeding of ornamental honeysuckles (Lonicera, Caprifoliaceae). Acta Hort. 320:127-132.
Gorchov, D.L. and D.E. Trisel. 2003. Competitive effects of the invasive shrub, Lonicera maackii (Rupr.) Herder (Caprifoliaceae), on the growth and survival of native tree seedlings. Plant Ecol. 166:13-24.

Guo, Z. and D. Wan. 2005. Studies on the chemical constituents of volatile oils from the dry flower buds of Lonicera hypoglauca. Chinese J. Mod. Appl. Pharm. 6:35-39.

Huxley, A. 1994. The new royal horticultural society dictionary of gardening. Macmillan Press, London, UK.

Karhu, S.T. 1997. Axillary shoot proliferation of blue honeysuckle. Plant Cell Tissue Organ Cult. 48:195-201.

Lee, S.J., K.H. Son, H.W. Chang, S.S. Kang, and H.P. Kim. 1998. Antiinflammatory activity of Lonicera japonica. Phytochem. Rev. 12:445447.

Li, H., P. Li, and W. Ye. 2003. Determination of five iridoid glucosides in flos lonicerae by highperformance liquid chromatography coupled with evaporative light scattering detection. J. Chromatography 1008:167-172.

Linsmaier, E.M. and F. Skoog. 1965. Organic growth factor requirements of tobacco tissue cultures. Physiol. Plant. 18:100-127.

Lloyd, G. and B. McCown. 1980. Commerciallyfeasible micropropagation of mountain laurel, Kalmia latifolia, by use of shoot-tip culture. Comb. Proc. Internat. Plant Propag. Soc. 30:421-427.

Murashige, T. and F. Skoog. 1962. A revised medium for rapid growth and bioassays with tobacco tissue cultures. Physiol. Plant. 15:473479.

Ochatt, S.J. 1991. Requirements for plant regeneration from protoplasts of the shrubby ornamental honeysuckle, Lonicera nitida cv. Maigrun. Plant Cell Tiss. Org. Cult. 25:161-167.

Palacios, N., P. Christon, and M.J. Leech. 2002. Regeneration of Lonicera tatarica plants via adventitious organogenesis from cultured stem explants. Plant Cell Rpt. 20:808-813.

Peng, Y., F. Liu, and J. Ye. 2005. Determination of phenolic acids and flavones in Lonicera japonica Thumb. by capillary electrophoresis with electrochemical detection. Electrophoresis 17:356-362.

Rout, G.R., S. Samantaray, and P. Das. 2000. In vitro manipulation and propagation of medicinal plants. Biotechnol. Adv. 18:91-120.

Schierenbeck, K.A. 2004. Japanese honeysuckle (Lonicera japonica) as an invasive species: History, ecology, and context. Crit. Rev. Plant Sci. 23:391-400.

Skirvin, R.M., K.D. McPheeters, and M. Norton. 1994. Sources and frequency of somaclonal variation. HortScience 29:1232-1236.

Wang, X., J. Luo, and Q. Song. 2004. Breeding new cultivars of Lonicera macranthoides HandMazz. Hunan Forest Sci. Technol. 31:15-17. (in Chinese).

Wang, X., A. Yi, Q. Song, Q. Nie, and Y. Li. 2005. Germfree tissue culture system establishment of new varieties in Lonicera Macranthoides. Nonwood Forest Res. 23:14-16. (in Chinese).

White, P.R. 1963. The cultivation of animal and plant cells. 2nd Ed. Ronald Press, New York, NY.

Windholz, M. 1976. The Merck index. 9th Ed. Merck and Co., Rahway, NJ.

Xu, B. and J. Wang. 1988. Lonicera L, p. 143-259. In: Xu, B. (ed.). Flora reipublicae popularis sinicae. Science Press, Beijing, China.

Yang, H., B. Yuan, L. Li, H. Chen, and F. Li. 2004. HPLC determination of pharmacokinetics of chlorogenic acid in rabbit plasma after an oral dose of flos lonicerae extract. J. Chromatography 42:173-176.

Zhou, R. and Q. Tong. 2003. Comparative study on content of chlorogenic acid in Lonicera japonica and $L$. macranthoides. Zhong Yao Cai 26:399-400. (in Chinese). 